\title{
Recepción de la literatura mexicana en la prensa española, durante la transición del siglo XIX al XX
}

Carlos Ramírez Vuelvas Universidad de Colima

Resumen

A finales del siglo XIX, el sistema literario mexicano planteó nuevos mecanismos de comunicación con la literatura española, como parte del reconocimiento cultural que proponía la sociedad mexicana en el proceso de construcción de su identidad nacional. Así, en la transición del siglo XIX al XX, la participación de los escritores mexicanos en la prensa española permitió la consolidación del proyecto, al mismo tiempo que sumaba piezas de la recepción de la literatura mexicana. Esta recepción no estuvo exenta de dificultades, que con el tiempo presentaron diversos matices que incluían: prejuicios culturales, juicios morales y sentencias políticas.

Palabras clave: recepción, identidad, exotismo, Modernismo.

Abstract

In the late nineteenth century, the Mexican literary system created new mechanisms of communication with the Spanish literature, as part of the proposal of Mexican society for cultural recognition in the process of building their national identity. Thus, on the transition of the nineteenth to the twentieth century, the involvement of Mexican writers in the Spanish press allowed the consolidation of the project, at the same time adding pieces of the reception of Mexican literature. 
This reception was not without difficulties, with different nuances over time including: cultural biases, moral judgments and political statements.

Keywords: Reception, Identity, Exoticism, Modernism.

\section{Recepción: prensa y antologías}

finales del siglo XIX, vivir en Europa (sobre todo en París o en
Madrid) se convirtió en un requisito para que los intelectuales mexicanos ocuparan el puesto de escritor, tanto en el escenario de su literatura nacional como en el de la comunidad literaria de la lengua espańola. Desde entonces, en España se leyó con más detenimiento la literatura mexicana, por lo que México, que comenzaba a construir sus propias estructuras sociopolíticas de soberanía estatal, envió a varios de sus personajes más eminentes a Madrid para que difundieran imágenes del progreso cultural mexicano.

La prensa periódica en España fue fundamental para la difusión y recepción de la cultura mexicana, en especial de la literatura. En este proceso destacaron los siguientes medios impresos: El Álbum Iberoamericano (1883-1910), Alrededor del Mundo (1899-1930), La América (1857-1886), La Esfera (1914-1931), La España Moderna (1889-1914), España y América (1892), El Globo (18751896), La Iberia (1854-1898), La Ilustración Católica de España (1897-1899), La Ilustración Española y Americana (1869-1921), La Ilustración Hispanoamericana (1881-1891), La Ilustración Ibérica (1883-1887), Por Esos Mundos y Renacimiento Latino (19051908). De igual forma, otros antecedentes culturales propiciaron la recepción de la literatura mexicana en Espańa, como la publicación en editoriales ibéricas de antologías y florilegios de poesía mexicana durante las primeras tres décadas del siglo XIX; la estancia de José Zorrilla en México, de 1854 a 1866; la presencia 
de escritores y periodistas españoles en nuestro país (Casimiro del Collado, Niceto de Zamoacois y Anselmo de la Portilla, antes de 1850; después, Telésforo García, Enrique de Olavarría y Ferrari y Santiago Ballescá, quienes enviaban colaboraciones a la prensa periódica española); además de las colaboraciones que Emilio Castelar publicaba en periódicos y revistas españolas a partir de 1860, que motivaron un imaginario peculiar sobre temas de las relaciones entre México y Espańa, como la llegada de Colón a América, la Conquista de México o el desarrollo del liberalismo en Hispanoamérica.

En ese contexto, en 1877 Enrique de Olavarría y Ferrari publicó en Revista de Andalucía varios artículos donde abordaba temas de literatura mexicana e incluyó una selección de piezas literarias. Juan de Dios Peza lo instó a que reuniera esos trabajos en un volumen, con miras a escribir una antología sobre la actualidad de la literatura mexicana (Peza, 1966: 153). No obstante, no fue en Madrid sino en su natal Málaga donde Olavarría y Ferrari publicó El arte literario en México. Noticias biográficas y criticas de los más notables escritores (1877). Un año después, con ligeras enmiendas y añadidos, lo reeditó en Madrid con el título Poesías líricas mexicanas (1878). Impulsado por "la necesidad moral" de difundir una antología aún más completa que las presentadas por Olavarría, el segundo secretario de la legación mexicana en España, el poeta Juan de Dios Peza, publicó en 1879: La lira mexicana. Colección de poesías de autores contemporáneos. El libro incluyó un prólogo, de Antonio Balbin de Unquera, y cartas, a manera de presentación, de Emilio Castelar, Ramón de Campoamor, Antonio F. Grilo, Antonio Hidalgo de Morbellón, Fernando Martínez Pedrosa, Gaspar Núñez de Arce y José Selgas.

La antología motivó largos comentarios en el periódico El Glo$b o$, en su edición del 16 de julio de 1879 , que se podrían sintetizar en los siguientes términos: 
1) Es natural la tendencia del escritor mexicano a describir el paisaje en el que ha crecido, "el seno de la más rica y hermosa naturaleza”. Por ello, no existe realmente una poesía mexicana, del mismo modo que no existe una "cultura mexicana", porque si existen expresiones culturales en este país éstas se deben

2) a "que llevan en sus venas la sangre hirviente de los aventureros espańoles", lo cual enfatiza la dependencia de crear la cultura a partir del paisaje idílico mexicano (propio de la aventura y la incertidumbre) en la misma medida que Andalucía creó "la más exuberante poesía que se conoce".

3) El renglón final subraya el efecto exotista del crítico, que practica un asombro, digámoslo así, abismado, puesto que "lo maravilloso sería que la poesía mexicana no fuera un eco lejano de la poesía nacida en las comarcas andaluzas" (Sin firma, 1879: 1).

El 30 de julio de 1879, el crítico y periodista español Guillermo Graell publicó en La Ilustración Española y Americana dos ensayos en los que diseñó un modelo de periodización de la literatura

${ }^{1}$ Sobre la poesía mexicana como poesía méxico-andaluza, aparecieron varios comentarios en la prensa periódica española. Uno de ellos fue publicado el 28 de marzo de 1880 en La América y dibujaba un farragoso cuadro de México, descrito aún como colonia espańola. El propósito del texto era difundir la cultura mexicana bajo la siguiente premisa: "Los mexicanos son, por lo general, inteligentes, audaces y brillantes, como los españoles; y suaves, cautos y estoicos, como los indios". En ese sentido, se estableció otro símil entre las letras mexicanas y las andaluzas, sólo que ahora con las mujeres como eje: "debemos afirmar que más que hermosas son buenas, dulces y discretas: son como las andaluzas, que, aunque no sean bellas, son irresistibles; y casi puede afirmarse que no existe mujer que posea la plenitud de su sexo como las mexicanas" (Varios americanos, 1880: 8-10). El periodista Ramón Elices Montés publicó opiniones parecidas en su obra Cuatro años en México. Memorias intimas de un periodista español (1885), donde insistió en las similitudes entre la cultura andaluza y la mexicana, basándose en las siguientes características compartidas: chulería, pereza, informalidad, gusto por la monta de caballos y el uso de armas; particularidades que el autor atribuye a la herencia cultural musulmana en Andalucía. 
mexicana y, a diferencia de lo expuesto por El Globo, planteó que para valorarla era necesario comprender que no se trataba de una extensión de la cultura hispánica, sino de la gestación de una cultura literaria particular. Sin embargo, no faltó el matiz exótico de quien define, antes de leer, a la literatura mexicana: "una poesía que fascina por una pompa que refleja la vegetación tropical, y cuyas imágenes, llenas de luz y del fuego del sol de México, inflaman nuestra fría fantasía"; más adelante insistió: "Los poetas mexicanos más notables se distinguen por una musa retozona y alegre, o por una pompa de estilo que refleja la fastuosa y exuberante vegetación americana"; para luego matizar: "Allí, como aquí, se prefiere el giro y la forma del pensamiento al pensamiento mismo" (Graell, 1879: 9-10).

\section{Una serie de lecturas conservadoras}

En 1878, el periodista católico Victoriano Agüeros comenzó a publicar en La Ilustración Española y Americana una serie de artículos sobre la cultura literaria de México, los cuales se sumaron como otra pieza de la recepción de la literatura mexicana en Madrid. Estos ensayos obtuvieron resultados desiguales, por lo que no faltó la crítica, sobre todo en México. La mayoría de estos textos eran comentarios de tinte biográfico que su autor reunió, posteriormente, en el libro Escritores mexicanos contemporáneos (1880). Sin embargo, no todos los ensayos fueron cronologías intelectuales. Por ejemplo, en el artículo del 22 de julio, Agüeros intentó hacer una historia de la literatura mexicana que incluyera tanto la nómina de las primeras publicaciones periódicas del siglo XIX como un registro de nombres de los escritores mexicanos.

Hacia las últimas décadas del siglo XIX, algunos críticos españoles comenzaron a ocuparse con más detalle de la literatura mexicana. Marcelino Menéndez Pelayo presentó sus primeros cursos 
de literatura española, donde analizó, como un tema especial, la literatura mexicana. Además, Antonio Fernández Merino publicó Poetas americanos. México. Flores, Hijar, Prieto, Riva Palacio, Peza, Carpio, Altamirano (1886), cuyo discurso sintetiza las opiniones dominantes sobre la literatura mexicana en Espańa: "Nos hallamos en presencia del paisaje más encantador que puede soñarse: nuestras miradas se pierden en la dilatada extensión del lago Maggior [sic], a uno y otro lado, como brotando de sus tranquilas aguas, se ven altísimas montańas escuetas y pedregosas, unas sombrías y melancólicas, otras de lujuriosa vegetación, rica en tonos alegres las demás” (Fernández Merino, 1886: I).

En este tono, también fueron relevantes las obras México contemporáneo (1889), de Francisco de Prida y Arteaga y de Rafael Pérez Vento, América y sus mujeres (1890), de la Baronesa de Wilson, y la Antología de la poesía hispanoamericana (1892), realizada por Marcelino Menéndez Pelayo por encargo de la Real Academia Española en ocasión del IV Centenario del Descubrimiento de América, la cual merece una mención especial (y un capítulo aparte). La Antología provocó una gran reacción crítica en las dos orillas del Atlántico, por lo que, después de su publicación, surgieron varios manuales y antologías similares como: La literatura española del siglo XIX (1891-1893), de Francisco Blanco García, y Literatura hispanoamericana (1896), de Manuel Poncelis.

En la prensa, estos nuevos acercamientos críticos sobre las letras mexicanas fueron compartidos por el académico Antonio Balbín de Unquera que, entre el 25 de marzo y el 5 de abril de 1890, publicó en La Ilustración Católica tres artículos sobre literatura mexicana para conocer el "secreto de su personalidad en su expresión poética". Sus artículos se basan en tres antologías: El arte literario en México, de Enrique de Olavarría y Ferrari, La lira mexicana, de Juan de Dios Peza, y otra que "ha comenzado a ver la luz en México bajo la protección del actual representante de la República 
en Madrid" y que probablemente se refiere al Parnaso mexicano (1885-1902), que por entonces publicaba Vicente Riva Palacio.

Sobre la nueva poesía mexicana, Balbín de Unquera criticó la falta de referencias a la tradición lírica castellana, un señalamiento que ya había expuesto Menéndez Pelayo: "Mucha parte de la poesía mexicana del siglo actual no lleva impresos los caracteres del país que la vio nacer, y en estas ligeras observaciones no podemos insistir en los autores que la representan"; no obstante, a diferencia de don Marcelino, Unquera considera que esta "negación al pasado" le permitía a la literatura mexicana comprender mejor las nuevas escuelas estéticas encabezadas por los poetas que practicaban una lírica contemporánea, "incrédula, desesperada, huyendo de los altares y de los templos para formarse, no sabemos qué santuario y sacerdotes, suspirando, gruńendo siempre, acercándose a la muerte para arrancarle su secreto, ya que no puede el de la vida" (Balbín de Unquera, 1890: 78).

Balbín de Unquera es probablemente el primer crítico de la lengua espańola en asegurar que la caracterización de la poesía mexicana se debe a su capacidad sensorial de unir percepciones con objetos de enunciación. Tal vez por lo mismo, dedicó varios párrafos para disertar sobre la poesía amorosa en el mundo grecolatino, lo que le permitió afirmar que en la lengua espańola no existe ninguna otra tradición poética tan rica en su expresividad amorosa como la mexicana, cuyos primeros representantes fueron Manuel Acuña y Manuel M. Flores, y que este tipo de poesía es la versión contemporánea del género lírico.

\section{Polémicas modernistas en la prensa de Madrid}

El poeta Francisco A. Icaza arribó a Madrid en 1886, al frente del Modernismo mexicano en España. La prensa matritense difundió a otros escritores identificados con el Modernismo, como 
Manuel Gutiérrez Nájera y Salvador Díaz Mirón, “probablemente el primero de los modernistas hispanoamericanos que se diera a conocer como poeta en España” (Fogelquist, 1968: 228). Al llegar a la capital de España, Icaza se encargó de difundir dos poemas de Díaz Mirón: "A Gloria”, que apareció el 7 de enero de 1886 en el periódico La Discusión, y "El desertor", que se publicó el 22 de septiembre de 1888 en La Ilustración Española y Americana. Aunque el filólogo Donald Fogelquist señala que la recepción sobre la poesía de Díaz Mirón no comenzó hasta 1894, los comentarios sobre su persona y obra ya descollaban incluso desde la década de los sesenta del siglo XIX. Aunque es cierto que poco se le conocía como poeta (prácticamente sólo el mote), tenía algo de fama como político y hombre de acción: el periódico La Discusión advirtió sobre su combate en el campo de batalla contra el ejército francés durante la ocupación de Maximiliano de Habsburgo en México; La Época añadió que había participado en el gobierno de Benito Juárez como gobernador de Veracruz, y La Ilustración Española y Americana destacaba que fue editor de la Revista Veracruzana. En el periódico El Imparcial, el escritor venezolano Miguel Eduardo Pardo fue el primero en comentar con prolijidad la obra de Díaz Mirón, en un artículo publicado el 15 de enero de 1894, en donde afirmaba: no hay "en la lírica mexicana quien lo sobrepuje en genio".

Esta intervención en las prensas matritenses habría definido la recepción positiva de la obra de Díaz Mirón. Sin embargo, Fogelquist comete un error al seńalar que la principal virtud del ensayo de Miguel Eduardo Pardo fue presentar un poema definitivo en la difusión de la obra poética del mexicano en Espańa y en toda Hispanoamérica: “A Gloria”, poema que en 1886 ya se había publicado en la prensa matritense, gracias a la intervención de Francisco A. de Icaza. También, hay que considerar que el poema "Deseos", no advertido por Fogelquist, mantiene retórica y estéticamente 
características similares con "A Gloria” y fue difundido el 7 de diciembre de 1890 por la revista Álbum Iberoamericano. Fogelquist sugiere que en "A Gloria" hay estructuras poéticas cercanas a las propuestas modernistas, una de ellas es el verso endecasílabo como un homenaje a los orígenes de la lírica española. "Deseos" está escrito en endecasílabos propios, con acentos en la tercera, la sexta y la décima sílaba. El uso del yo lírico en primera persona recuerda a la poética de Bécquer y confirma el uso de un "lenguaje relumbrante, brioso y varonil”, como asegura el filólogo norteamericano.

El 26 de mayo de 1895, la aparición del poema "Redemptio" en La Correspondencia de España ayudó para que la recepción espańola definiera a Díaz Mirón como "una persona de acentuado individualismo" (lo que era valorado positivamente), a pesar de la marcada influencia del romanticismo francés. "Redemptio" sirvió para que el crítico Francisco Navarro Ledesma argumentara dos hipótesis sobre el poeta mexicano: su distanciamiento estético de la poesía decadentista (con poca identificación entre los lectores espańoles) y el uso de un yo lírico definido por una personalidad "castiza y clásica" (más seductora para el público español). ${ }^{2} \mathrm{~A}$ diferencia de los comentarios que se hacían en México sobre Díaz Mirón, en el sentido de que su poética romántica devenía de la asimilación de las poéticas de Víctor Hugo o de Lord Byron, Navarro Ledesma veía en el poeta mexicano una personalidad propia: "Por fortuna esta admiración ciega [por Víctor Hugo y por Lord Byron] no ha logrado extraviar a Díaz Mirón, como a otros poetas americanos, porque en él había la estrofa de un verdadero poeta es-

${ }^{2}$ Los poemas de Díaz Mirón se reprodujeron en diversos medios impresos. Pronto recibió más críticas que no siempre fueron positivas, como la lectura irónica de Ricardo Catarineu, quien acusaba a la poesía del mexicano de "tener muchos ripios y ser rimbombante hasta la exageración”. Aún así, continúa el periodista español: "no deja de haber compuesto poesías muy atractivas por lo sentidas y sinceras" (Catarineu, 1899: 1). 
pańol, y tan español, que en algunas composiciones suyas se notan resabios de gongorismo" (Navarro Ledesma, 1898: 243).

En 1901, cuando publicó en México su libro de poesía Lascas, Díaz Mirón era un viejo conocido de la prensa española que no tardó en reproducir sus poemas: “¿Qué es poesía?”, "La poesía”, "Cleopatra”, "A Byron” y "Gorjeos", los cuales concitarán una recepción igual de problemática que sus primeros poemas publicados en la Villa y Corte. Redactores de La Época, El Globo, La Ilustración Española y Americana, Madrid Cómico y El Imparcial pronto emitieron comentarios que iban desde la crítica a las extravagancias de Díaz Mirón hasta la celebración porque el poeta mexicano emitía verdaderas "chispas" de poesía.

La dubitación con que la recepción española leyó la literatura de Díaz Mirón fue similar al caso de la obra dispersa y fragmentada de Manuel Gutiérrez Nájera, otro poeta que Francisco A. de Icaza difundió apenas llegó a Madrid. La variedad de géneros practicada por Nájera complicaba aún más su lectura. Además de la poesía, a la que se sentía consagrado (aunque nunca viera publicado un libro de poesía propia), también practicaba la crónica y la crítica literaria. En 1887, cuando fue electo miembro de la Academia Mexicana de la Lengua correspondiente de la Real Espańola, en Madrid aparecieron las primeras críticas en su contra (Sin firma, 1887: 4). Sin embargo, fue por su faceta de articulista que Antonio de Valbuena le atacó “con truculencia”, en respuesta a algunos textos periodísticos que Nájera había escrito en México en contra del académico (Fogelquist, 1968: 245).

Salvador Rueda fue el primer poeta español encargado en resarcir la imagen de Gutiérrez Nájera, al grado de recuperar los ritmos y las figuras retóricas de las composiciones fechadas en 1888 (Fogelquist, 1968: 245); no obstante, fue en el libro El ritmo (1894) donde Rueda habló de Gutiérrez Nájera como uno de los modernistas hispanoamericanos más importantes. En 1892, apareció 
uno de los primeros poemas de Nájera en la prensa española, "To be", en la revista España y América; dos años después, La Ilustración Ibérica publicó "Para el corpiño"; en 1899, El Álbum de Madrid dio a conocer "Mariposas", y en 1907, El Ateneo de Madrid publicó "La duquesa Job”. El poeta mexicano murió en 1895, mientras su obra fluía aún con lentitud en España.

Sólo después de publicar los poemas de sus maestros, Icaza remitió dos composiciones de su autoría a La Ilustración Española y Americana: "Estancias" y "La leyenda del beso". La reproducción de estos poemas en varios medios impresos confirma la rápida popularidad de Icaza en la recepción matritense, la cual fue constante con el resto de su obra. Por ejemplo, la publicación en 1892 de su primer libro de poesía, Efímeras, suscitó rápidamente cinco comentarios críticos, favorables al poeta, publicados en La Epoca, El Globo, El Imparcial y La Ilustración Española y Americana.

Entre 1892 y 1900, en la prensa española también se difundieron varios poemas de escritores que, posteriormente, la tradición literaria consideraría como modernistas, ya sea porque su retórica apunta al uso de dicho movimiento o porque las ideas de su discurso estético pertenecen al Modernismo, como Agustín F. de Cuenca, Balbino Dávalos, Carlos Díaz Dufoo, Manuel Díaz Mirón, Enrique Fernández Granados, Manuel María Flores, Laura Méndez de Cuenca, Luis G. Ortiz, Manuel José Othón, José Peón Contreras, Ignacio Pérez Salazar, Enrique Pérez Valencia, Efrén Rebolledo, José Juan Tablada, Luis G. Urbina y Jesús Urueta, quienes para ese entonces ya habían publicado en alguno de los periódicos o revistas de Espańa.

En 1898, por encargo de la editorial barcelonesa Casa Maucci, apareció una presentación del Modernismo mexicano en el volumen Los trovadores de México, una selección de poetas atribuida a Juan de Dios Peza. En los liminares del volumen, los editores aclaman en su dedicatoria: "A los trovadores americanos: a esa plé- 
yade de sońadores vírgenes, que así afilan la espada en la lira, para defender su independencia, como lloran, o ríen o cantan con el alma, reproduciendo en sus versos cuanto de sublime encierra el Nuevo Mundo". En el índice de la edición destacan: Agustín F. Cuenca, Salvador Díaz Mirón, Manuel Gutiérrez Nájera, Balbino Dávalos, Adalberto A. Esteva, Amado Nervo, José Juan Tablada y Manuel José Othón, entre otros. Cuatro años después, el volumen fue reeditado por la misma editorial y distribuido en Barcelona y en Madrid; además, sirvió como base para la publicación de la antología Parnaso mexicano (1910), de Adalberto A. Esteva, ${ }^{3}$ que nació con la intención de presentar a los lectores españoles a la segunda generación de poetas modernistas o decadentes mexicanos: Rubén M. Campos, Jesús E. Valenzuela, Balbino Dávalos, Amado Nervo, José Juan Tablada y Francisco Olaguíbel: "el brillante escuadrón que sostiene en el estadio de la prensa de México la causa de la poesía decadente” (Esteva, 1910: 15).

Polarizada, la recepción española saludó a los modernistas mexicanos con lentitud y espasmo. Los periodistas, los críticos literarios y los escritores más conservadores, reclamaban que los jóvenes hispanoamericanos buscaban "ingenio" en culturas ajenas al espańol. "No es de extrañar, en rigor, que los literatos americanos se afrancesen, cuando aquí, poco o mucho la inmensa mayoría de nuestros escritores se han afrancesado también”, escribía, entre atónito y rabioso, el filósofo José Verde Montenegro en La Correspondencia de España (1899: 1). Más punzantes fueron los reproches publicados en El Globo, el 10 de septiembre de 1900, bajo el seudónimo "Lorena", atribuido al periodista Manuel Bueno, en donde se aseguraba que "ninguna región de América tiene literatura propia. Se vive de prestado, a expensas de sugestiones intelectuales ajenas,

${ }^{3}$ La cual cuenta con un antecedente de la misma Casa Maucci: El parnaso mexicano. Antología completa de sus mejores poetas (1909), una selección realizada por el periodista argentino José León Pagano. 
y no se escribe sobre las maravillas de nuestros clásicos, sino con el prurito de imitar en francés, adicionándole un vocabulario de modismo que asusta" (1900: 1).

Desde El Imparcial, Manuel Bueno polemizó con otro periodista, dramaturgo y poeta ocasional, Ricardo Catarineu, que colaboraba en La Correspondencia de España. Catarineu fue uno de los receptores más agudos del Modernismo hispanoamericano, movimiento al que Bueno llegó a caracterizar como una aberración lírica que avergonzaba a la lengua espańola por su amaneramiento afrancesado: "Hoy los hispanoamericanos se orientan literariamente hacia París adoptan la estética de los escritores franceses, leen sus libros, se los asimilan y procuran imitarlos" (1907: 3-4). Como ejemplos positivos de "escritores modernistas" citó a autores mexicanos como Díaz Mirón, Francisco de Icaza y Gutiérrez Nájera, quienes "habrán acomodado su léxico a la ortodoxia castellana [Icaza sobre todo], pero sus almas no nos son enteramente extrańas. El fondo espańol de su sensibilidad de poetas aparece tan mitigado que apenas puede notarse como indicio de atavismo" (1907: 4).

Pasados los ańos de los primeros aspavientos en torno al Modernismo, los escritores jóvenes de España fueron más receptivos con las nuevas letras mexicanas. Enrique Diez-Canedo escribió en la revista La Lectura sobre Efrén Rebolledo: un "poeta parnasiano, de forma impecable, apasionado de orientalismo, persigue lo pintoresco a todo trance, y para conseguirlo, no vacila en emplear, a veces sin la preparación necesaria para que no detonen, muchas palabras exóticas. Su manera de ver es neta y precisa” (1908: 440). Sobre los versos de Manuel José Othón, apuntó César E. Arroyo: tiene "arpegios de selvas, como arpas eólicas; lamentos de ríos, como órganos clamorosos; bramar de olas y tronar de volcanes, toda, en fin, la magna sinfonía orquestal del universo" (1918: 115). De igual forma, Arroyo mostró al público español al poliva- 
lente José Juan Tablada, definido como "un artista que, después de haber realizado una obra considerable, universalmente admirada, dentro de las escuelas que se llamaron modernistas, decadentistas, simbolistas, parnasianas, se le revela el misterio atractivo e inquietante del arte novísimo y hacia él evoluciona y adapta su espíritu flexible y sutil" (Arroyo, 1919: 107). Miguel de Unamuno reseñó la obra de Jesús Urueta, "un hombre de cultura y de buen gusto" (1904: 454), y Manuel Ugarte a Jesús Valenzuela: "que ha hecho tanto en favor de las letras mexicanas, y que es uno de los espíritus más altos y más generosos de América” (1906: 17).

En enero de 1901, en el número inaugural de la revista Nuestro Tiempo, que convocaba a los jóvenes escritores espańoles entorno a los ideales de regeneración cultural impulsados por Miguel de Unamuno, Francisco A. de Icaza publicó el ensayo "Poetas modernos de México (antología íntima)”, donde caracterizó al Modernismo a partir de la oposición entre arte antiguo y arte moderno. En las galerías, los museos y las antologías del arte antiguo se exhiben "reliquias de lo pasado [...] cuyo único mérito es la antigüedad", en tanto que "para conocer el arte contemporáneo hay que estudiarlo en las galerías privadas" . Así, Icaza confirmó que su definición sobre la modernidad literaria se basaba en la comprensión de la vida íntima (descrita por el arte moderno) en oposición a la vida pública (que describió el arte antiguo). Además, al destacar el "preciosismo literario" de Manuel Gutiérrez Nájera y de Salvador Díaz Mirón señaló otra cualidad del Modernismo en la minuciosa construcción retórica de los poemas, lo que explicó en los siguientes términos: "mientras Gutiérrez Nájera, cuando acierta, funde

${ }^{4}$ El mismo artículo fue publicado en 1923 con el título "Letras mexicanas", en Revista de Libros. La variante más relevante respecto al texto original fue la inclusión de comentarios sobre otros dos poetas mexicanos: Manuel José Othón y Luis G. Urbina. 
bronces sin lacra y esculpe mármoles tersos, Díaz Mirón hace mosaicos, joyas bizantinas y vidrieras de colores" (1901: 35).

\section{Nuevas imágenes del México nuevo}

Al comenzar el siglo XX, los intelectuales de las dos orillas comenzaron a registrar formas diferentes para comprender la cultura y la literatura de ambos países. Uno de estos documentos fue escrito por Nicolás León con el título Compendio de la historia general de México, que apareció en 1901 en Madrid. Otro libro que causó polémica fue Carácter de la conquista española en América y en México, según los textos de los historiadores primitivos, de Genaro García, publicado en 1901 en México. Esta obra fue ampliamente debatida en la Real Academia de Historia, donde Cesáreo Fernández Duro consideró que Genaro García ni siquiera hablaba de los pueblos americanos, ya que desconocía la vida de estas poblaciones. También Rafael Altamira leyó cuidadosamente la obra de García y emitió un juicio que coincide con el de Fernández Duro: "En ese libro la exactitud histórica ha sido sacrificada a una tesis preconcebida, y que por esto debe ser leído y aprovechado con gran precaución, incluso en los datos ciertos que contiene" (Altamira, 1904: 349).

La aparición de estos textos, durante un momento peculiar de las relaciones entre México y España (justo después de la pérdida de las últimas colonias ibéricas), generaba nuevas imágenes de la sociedad mexicana. El movimiento cultural mexicano, que afirmaba la identidad nacional por medio de sus textos históricos, contrastaba con el periodo de depresión por el que cruzaba la sociedad española. Se trataba de la construcción de imágenes de un México nuevo, que los intelectuales mexicanos exploraban desde varios ángulos. En este sentido, Justo Sierra era un personaje central, tanto por el capital simbólico gestado en su país como por su acercamiento al campo cultural matritense. Por eso se deben 
revisar cuatro casos concretos sobre la difusión del México nuevo ideado por Sierra (y en su momento por Amado Nervo) posicionado en el campo cultural español:

I. La constitución de la Academia Mexicana de la Historia, que llevaba una decena de años construyéndose en el aire, dio uno de los pasos más importantes (aunque no definitivos, porque le faltarán aún otros diez años de gestión) en 1901, cuando Sierra encabezó los nombres de posibles miembros fundadores, acompañado por Ignacio Mariscal, Alfredo Chavero, José María Roa Bárcena, José María Vigil, Francisco del Paso y Troncoso, Francisco Plancarte, entre otros. No obstante, aunque llegó a sesionar en México enviando la minuta de trabajo a Madrid, el proyecto desapareció poco tiempo después.

II. La creación del Ateneo Científico Literario de México, también impulsado por Justo Sierra a su regreso de la experiencia matritense de 1901. Este Ateneo mexicano, presidido por Juan de Dios Peza, fue una presunta corresponsalía del Ateneo de Madrid. Los medios españoles interpretaron el hecho como un gesto de filiación con los valores ibéricos en los siguientes términos:

México ha comprendido que no sólo en la esfera de la inteligencia aquellas repúblicas emancipadas deben guardar con la noble madre a quien deben los gérmenes de su civilización y los caracteres de su fisonomía nacional, el vínculo del habla, cuyas artísticas producciones constituyen el símbolo de toda cultura que tiene por fundamento orígenes seculares tan ilustres como lo son los de nuestra literatura nacional (Pérez Guzmán, 1901: 390-391).

Además, decía La Ilustración Española y Americana, en su edición del 22 de julio de 1901, que con este hecho se reconocían los lazos de "sangre" y "raza” entre México y Espańa. Es decir, los organismos como el Ateneo, asentaban políticamente la unidad biológica entre las dos naciones. 
III. Los artículos y reportajes que Amado Nervo publicó en $\mathrm{La}$ Ilustración Artística, de Barcelona, durante casi un año, entre el 27 de octubre de 1902 y el 3 de octubre de 1903..$^{5}$ En España, Nervo ya era conocido por medio de su poesía, mezcla de neomisticismo y modernismo, como la calificaban la mayoría de sus comentaristas. En La Ilustración Artística, Nervo creó la columna "Gentes y cosas de México" donde difundió el desarrollo alcanzado por México en las áreas de cultura, educación e industria. Su primer texto fue una semblanza de Justo Sierra como escritor, historiador, profesor y tribuno. Sin embargo, uno de los reportajes más interesantes fue el titulado "México nuevo", que apareció acompańado con varias fotografías que demostraban las afirmaciones de Nervo: "La vieja ciudad colonial, la perla de la corona española en América, la secular metrópoli azteca, llamada por Humboldt en un momento de buen humor 'ciudad de los palacios', aspira ya a merecer este nombre" (Nervo, 1903: 201). En la mayor parte del artículo, se destacan los avances urbanos de la capital del país y la construcción de edificios modernos. Ante el temor del poeta de que el fenómeno urbano desbordara la capacidad demográfica de la ciudad, optimista, señaló que "la migración europea" resolvería el problema con sus conocimientos.

IV. En el proceso de difusión de las imágenes del nuevo México, el proyecto más importante fue emprendido y coordinado por el mismo Justo Sierra, con la publicación de los dos tomos y tres volúmenes de la enciclopedia México: su evolución social. Sintesis de la historia politica, de la organización administrativa y militar y del estado económico de la Federación mexicana, de sus adelantos en el orden intelectual, de su estructura territorial y del desarrollo de su población y de los medios de comunicación nacionales e internacionales, de sus conquistas en el campo industrial, agricola, minero, mercantil, etc. (1900-1902). Como se puede observar, el libro trataba de dar

${ }^{5}$ Esta serie fue publicada nuevamente en la Revista del Ateneo entre 1906 y 1910. 
una imagen completa de la situación en que se encontraba México al comenzar el siglo XX. Para ello, Sierra invitó a colaborar a los investigadores y científicos mexicanos más importantes del momento: Agustín Arango, Porfirio Parra (responsable de los apartados dedicados a ciencia y literatura), Ezequiel Chávez, Manuel Sánchez Mármol, Carlos Díaz Dufoó, Bernardo Reyes, Julio Zárate, Jorge Vera Estańol, Gilberto Crespo y Martínez, Miguel Macedo, Pablo Macedo y Genaro Raigosa, quienes escribieron la historia y evolución de distintas áreas de la vida social, cultural, industrial y económica del país.

Para coronar el esfuerzo intelectual dedicado a la obra, Sierra gestionó con el gobierno mexicano que se contratara al editor Santiago Ballescá, el mismo editor que más una década atrás había publicado la enciclopedia de historia nacional México a través de los siglos, coordinada por Vicente Riva Palacio. Ballescá buscó la imprenta de Salvat e Hijos para imprimir el millar de ejemplares que les pedía el gobierno de México. Además, contrató los servicios de la casa de grabados Thomas, para diseñar las planchas de la impresión de las tipografías, y se encargó el diseño gráfico, incluido la ilustración con imágenes, a artistas como Apeles Mestres, Cabrinety, Cusach Pascó, Pellicer, Riquer y Utrillo, entre otros.

En España, el libro fue recibido con beneplácito porque se reconoció que los escritores participantes eran algunos de los intelectuales más distinguidos de México y porque se consideraba a este país una de las naciones más importantes de Hispanoamérica. A partir de entonces, se asentaron algunas de las bases culturales que permitieron tanto una comprensión objetiva de la literatura mexicana, más autónoma en la definición de los valores de identidad que la constituían, como una mejor recepción a los escritores que, a partir de 1912, llegaron a Madrid para difundir su obra literaria. 


\section{Fuentes}

Agüeros, Victoriano, 1880, Escritores mexicanos contemporáneos, México, Imprenta de Ignacio Escalante.

Altamira, Rafael, 1904, "Literatura histórica hispanoamericana", Nuestro Tiempo, núm. 42, año IV, p. 349.

Arroyo, César E., 1919, "La nueva poesía en América. La evolución de un gran poeta”, agosto, pp. 105-113.

, 1918, "Modernos poetas mexicanos. Manuel José Othón", octubre, pp. 113-117.

Balbín de Unquera, Antonio, 1890, "Poesía mexicana. I", La Ilustración Católica, t. XIII, núm. 9, año XV, pp. 78 y 80.

Blanco García, Francisco, 1891-1893, La literatura española en el siglo XIX, 3 tomos, Madrid, Saénz de Rubera.

Bueno, Manuel, 1907, "Estrofas de un poeta”, El Imparcial, núm. 14406, año XLI, pp. 3 y 4.

, 1890, "Poesía mexicana", La Ilustración Católica, t. XIII, núm. 10, año XV, pp. 111 y 112.

, 1890, "Poesía mejicana. III", La Ilustración Católica, t. XIII, núm. 11, año XV, pp. 103-105.

Catarineu, Ricardo J., 1899, "Lecturas. Versos", La Correspondencia de España, núm. 15216, año L, p. 1.

Díaz Mirón, Salvador, 1895, "Redemptio", La Correspondencia de España, núm. 13624, año XLVI, p. 4.

, 1890, "Deseos", El Álbum Iberoamericano, 2a época, núm. 17, ańo VIII, p. 201.

, 1886, "A Gloria", La Discusión, núm. 1997, año XXXI, p. 3.

, 1888, "El desertor", La Ilustración Española y Americana, núm. XXXV, año XXXII, p. 171. 
Diez-Canedo, Enrique, 1908, "Rimas japonesas, por Efrén Hernández", La Lectura, t. I, N, ańo VIII, p. 440.

Elices Montes, Ramón, 1885, Cuatro años en México. Memorias intimas de un periodista español, Emilio Castelar (prol.), Madrid, Imprenta de la viuda de J. M. Pérez.

Esteva, Adalberto A. y José Pablo Rivas, 1910, El parnaso mexicano. Antología completa de sus mejores poetas con numerosas notas biográficas, Barcelona, Maucci.

Fernández Duro, Cesáreo, 1901, "Carácter de la conquista española en América y en México según los textos de los historiadores primitivos", Boletín de la Real Academia de la Historia, pp. $399-411$.

Fernández Merino, Antonio, 1866, Poetas americanos. México. Flores, Hijar, Prieto, Riva Palacio, Peza, Carpio, Altamirano, Barcelona, Tipografía La Academia de Ullastres.

Fogelquist, Donald F., 1968, Españoles de América y americanos de España, Madrid, Gredos.

García, Genaro, 1901, Carácter de la conquista española en América y en México, México, Oficina tipográfica de la Secretaría de Fomento.

Graell, Guillermo, 1879, "La lírica mexicana”, La Ilustración Española y Americana, núm. XXVIII, año XXIII, pp. 9 y 10.

Gutiérrez Nájera, Manuel, 1907, “La Duquesa Job”, Revista del Ateneo, t. III, núm. XIII, año II, pp. 42-45.

, 1907, “Visión”, El Liberal, núm. 9948, año XXIX, p. 1.

, 1907, "Condenación de un libro", El Liberal, núm. 9948, año XXIX, p. 1.

, 1900, “Cita”, La España Moderna, núm. 133, año XII, pp. 78 y 79 . 
, 1899, "Mariposas", El Álbum de Madrid, núm. 13, año I, p. 2.

, 1892, "Poetas mexicanos. To be", España y América, núm. 44, año I, p. 497.

Hispanus, 1903, "Lecturas americanas", La España Moderna, núm. 179, año 15 , p. 144.

Icaza Francisco A., 1901, "Literatura americana. Poetas modernos de México (antología íntima). Manuel Gutiérrez Nájera y Salvador Díaz Mirón”, Nuestro Tiempo, núm. 1, año I, pp. 34-42.

, 1890, "Estancias", La Ilustración Española y Americana, núm. XXXIX, año XXXIV, p. 239.

, 1890, "La leyenda del beso", La Ilustración Española y Americana, núm. XLIV, año XXXIV, p. 330.

León, Nicolás, 1901, Compendio de la historia general de México, Madrid, Casa Sucesores de Rivadeneyra.

Lorena, 1900, "Volanderas. Para los literatos periodistas", El Globo, núm. 9046, año XXVI, p.1.

Menéndez Pelayo, Marcelino, 1942, Obras completas. Estudios y discursos de crítica histórica y literaria, vol. 7, Madrid, Consejo Superior de Investigaciones Científicas.

, 1984, Obras completas. Historia de la poesía hispano-americana (con indice de autores, titulos y materias), Enrique Sánchez Reyes (ed.), vol. 27, Santander, Aldus-Consejo Superior de Investigaciones Científicas.

, 2000, Antología de poetas hispanoamericanos, 4 tomos, Barcelona, Factoría Ediciones.

Navarro Ledesma, Francisco, 1898, "Poetas hispanoamericanos”, Unión Ibero-Americana, p. 243.

Nervo, Amado, 1903, "Gentes y cosas de México. México nuevo", La Ilustración Artística, núm. 1108, año XXII, pp. 200-206. 
Olavarría y Ferrari, Enrique, 1877, El arte literario en México. Noticias biográficas y criticas de sus más notables escritores, Málaga, Imprenta de la revista Andalucía.

, 1878, Poesías líricas mexicanas, Madrid, Imprenta Est. y Galv. de Aribau y Co.

Pagano, José León, 1909, El parnaso mexicano. Antología completa de sus mejores poetas, Barcelona, Maucci.

Pardo, Miguel Eduardo, 1894, "Poetas mexicanos", El Imparcial, núm. 9579, año XVIII, pp. 6 y 7.

Pérez de Guzmán, Juan, 1901, "El Ateneo Científico-Literario de México”, La Ilustración Española y Americana, núm. XXIII año XLVI, pp. 390-391.

Peza, Juan de Dios, 1966, Memorias, reliquias y relatos, México, Editora Nacional.

, 1879, La lira mexicana. Colección de poesías de autores contemporáneos, Madrid, R. Velasco Impresor.

, 1898, Los trovadores de México, Barcelona, Maucci.

[Peza, Juan de Dios], 1900, Los trovadores de México, Barcelona, Maucci.

Poncelis, Manuel, 1896, Literatura hispanoamericana, Madrid, Ramón Anglés Imprenta y Cromotipia.

Prida y Arteaga, Francisco de, y Rafael Pérez Vento, 1889, Méjico contemporáneo, Madrid, Establecimiento tipográfico de Fortanet.

Riva Palacio, Vicente, 2006, Parnaso Mexicano. Primera y segunda serie, Manuel Sol (Ed., intro., e índ.), José Ortiz Monasterio (coord.), México, Conaculta/UNAM/Instituto Mexiquense de Cultura/Instituto Dr. José María Mora.

Sin firma, 1887, "Ecos teatrales”, La Época, núm. 12442, año XXXIX, p. 4. 
, 1883, "Libros presentados", La Ilustración Española y Americana, núm. XLVI, ańo XXVII, p. 15.

, 1879, "Revista bibliográfica”, El Globo, núm. 1869, año V, p. 1.

, 1863, “La Discusión”, La Discusión, núm. 2210, año VII, p. 2.

1862, “Correspondencias extranjeras", La Época, núm. 4540, año XIV, p. 3.

Ugarte, Manuel, 1906, La joven literatura hispanoamericana. Antología de prosistas y poetas, París, Librería de Armand Colín. , 1907, “Crónica americana”, La Lectura, núm. 81, año VII, pp. $42-46$.

Unamuno, Miguel de, 1904, "Literatura hispano-Americana. Tres obras de estudios clásicos", La Lectura, t. III, núm. 45, año IV, pp. 453-456.

Varios americanos, 1880, "La república mexicana", La América, núm. 6, año XXI, pp. 8-10.

Verde Montenegro, José, 1899, "Nuestra literatura en América”, La Correspondencia de España, núm. 15187, ańo L, p. 1.

Wilson, Baronesa de [Emilia Serrano], 1903, El mundo literario americano. Escritores contemporáneos. Semblanzas. Poesías. Apreciaciones. Pinceladas, 3 tomos, Barcelona, Casa Editorial Maucci. , 1890, América y sus mujeres, Barcelona, Fidel Giro.

(Artículo recibido el 20 de marzo de 2014; aceptado el 7 de agosto de 2014) 
